\title{
EFEKTIVITAS MODEL DIRECT INSTRUCTION DALAM MENINGKATKAN KEMAMPUAN SISWA SMA NEGERI 1 BATAUGA MEMAHAMI NILAI DALAM FOLKLORE WANDIUDIU
}

\author{
Evaria $^{1}$, Asriani Abbas ${ }^{2}$, Muhammad Hasyim ${ }^{3}$ \\ ${ }^{1,2,3}$ Program Studi Bahasa Indonesia, Fakultas Ilmu Budaya Universitas Hasanuddin \\ evadandelion88@gmail.com \\ asriani.abbas66@gmail.com \\ hasyimfrance@unhas.ac.id
}

\begin{abstract}
This study aims to explain the application of the direct instruction model in improving the ability of students at SMS Negeri 1 Batauga to understand the value of Wandiudiu's folklore. It also explains the effectiveness of the direct instruction model in improving the ability of students of SMA Negeri 1 Batauga to understand the value of Wandiudiu's folklore. The type of research used is the type of classroom action research or commonly known as PTK (classroom action research). This class action research applies several cycles in implementation. The results showed that there was an increase in student learning process. Learning outcomes in the control class show differences. However, this difference does not indicate a significant improvement in learning outcomes. Cycle I reaches an average value of 70,61 and cycle II reaches an average value of 72,04. The results of both cycles are only in a sufficient category. Learning outcomes in the experimental class showed significant differences. Cycle I reached an average value of 78,87 and was in the sufficient category, while cycle II achieved an average value of 85,17 and was in a good category. The improvement of learning outcomes shows that the effective direct instruction model is used to improve the ability of students of SMA Negeri 1 Batauga to understand the values in Wandiudiu's folklore.

Keywords: direct instruction, student's ability, folklore, value
\end{abstract}

\section{PENDAHULUAN}

Setiap individu berhak memperoleh pendidikan. Pendidikan dalam prosesnya merupakan pembelajaran bagi peserta didik untuk memperoleh pengetahuan, keterampilan, dan menemukan hal-hal baru. Pendidikan pada umumnya terbagi dalam beberapa tahap, yaitu pendidikan anak usia dini (PAUD), sekolah dasar (SD), sekolah menengah pertama (SMP), sekolah menengah atas (SMA), dan perguruan tinggi.
Penelitian ini berfokus pada kegiatan pembelajaran yang ada di jejang sekolah menengah atas (SMA) yang ada di Buton Selatan. Jenjang pendidikan tersebut dipilih karena anak usia sekolah menengah atas dipandang sebagai individu yang mengalami rangkaian proses perkembangan pemikiran.

Dwi Siswoyo (2007: 18) menyatakan bahwa pendidikan merupakan proses yang dilakukan masyarakat dengan menggunakan lembaga pendidikan seperti halnya sekolah, perguruan tinggi, dan lembaga 
lainnya untuk memberikan pengetahuan mengenai budaya, nilai-nilai, dan keterampilan tertentu. Manusia dapat membina diri dan akhlaknya melalui pendidikan, sesuai dengan nilai-nilai yang ada dalam masyarakat dan kebudayaan.

$$
\text { Undang-Undang Republik }
$$

Indonesia tahun 2003 tentang Sistem Pendidikan Nasioanl yang tertuang pada Bab 1 Ketentuan Umum pasal 1 ayat 16 berbunyi sebagai berikut: Pendidikan yang berbasis masyarakat adalah penyelenggaraan pendidikan berdasarkan kekhasan agama, sosial, budaya, aspirasi, dan potensi masyarakat sebagai perwujudan pendidikan dari, oleh, dan untuk masyarakat. Selanjutnya, yang tertuang pada bab 3 UndangUndang Republik Indonesia tahun 2003 tentang prinsip penyelenggaraan pendidikan dalam pasal 4 ayat 3 , menyatakan bahwa pendidikan diselenggarakan sebagai suatu proses pembudayaa dan pemberdayaan peserta didik yang berlangsung sepanjang hayat.

Bunyi undang-undang di atas dapat disimpulkan bahwa pada hakekatnya tujuan pendidikan bukan hanya untuk mencerdaskan manusia, tetapi juga diharapkan dapat membentuk manusia yang berbudaya. Lingkup pendidikan tentunya bukan sebatas menjadi runag untuk semata-mata memperoleh ilmu pengetahuan bagi para siswa, akan tetapi diharapkan juga dapat membentuk peserta didik memiliki sikap peduli terhadap keberlangsungan kebudayaan. Berdasar pada undangundang tersebut, dapat dikatakan bahwa sekolah memiliki peran penting dalam proses pelestarian budaya. Sekolah bertanggung jawab untuk memperhatikan dan mengenalkan nilainilai budaya masyarakat kepada peserta didik.

Mata pelajaran Bahasa Indonesia merupakan salah satu mata pelajaran yang diajarkan di sekolah.
Cakupan materinya sangat luas, tidak hanya berfokus pada materi kebahasaan, tetapi juga kesusastraan. Kesusastraan merupakan semua ciptaan manusia dalam bentuk bahasa, baik lisan maupun tulisan yang mengandung nilai-nilai kebaikan dan nilai estetika. Sastra dalam pembelajaran bahasa Indonesia dapat membantu siswa berlatih keterampilanketerampilan. Adapun keterampilanketerampilan tersebut adalah menyimak, berbicara, membaca, dan menulis. Keterampilan berbicara akan menjadi bahan analisis dari keempat keterampilan yang ada. keterampilan berbicara akan dianalisis melalui kemampuan siswa menjelaskan nilainilai dalam folklore Wandiudiu.

Folklore Wandiudiu, sebagai salah satu sastra Buton akan menjadi materi ajar dalam penelitian ini. Ada banyak folklore yang berasal dari Buton, seperti Landoke-ndoke dan Lakolokolopua, Lacundu Bale, Randasitagi dan Wairiwondu, dan lain sabagainya. Folklore Wandiudiu dipilih karena menceritakan kisah antara anak dan kedua orang tuanya, yang mengandung nilai-nilai budi pekerti sehingga dapat dipelajari oleh siswa. Ada beberapa nilai yang terkandung dalam folklore Wandiudiu, namun dalam penelitian ini hanya akan fokus pada nilai religius, moral, sosial, dan budaya sesuai dengan nilai yang perlu ditemukan siswa dalam Rancangan Pelaksanaan Pembelajaran (RPP) di sekolah. Nilai-nilai dalam folklore Wandiudiu relevan dengan pilar-pilar pendidikan karakter. Karena itulah folklore tersebut bisa menjadi materi ajar yang digunakan oleh guru di dalam kelas untuk pembentukan karakter siswa.

Survei awal dilakukan pada hari Rabu, 24 Juli 2019 dan diperoleh informasi bahwa pembelajaran berkaitan dengan menemukan nilai dalam sastra lokal yang berasal dari Buton belum pernah dilakukan di SMA Negeri 1 


\section{1 | JURNAL ILMU BUDAYA}

Volume 8, Nomor 1, Juni 2020
Batauga. Buku pelajaran bahasa Indonesia yang ada di sekolah khususnya materi cerita rakyat hanya terdapat hikayat dari Malaysia. Selanjutnya, disampaikan untuk menggunakan folklore Wandiudiu sebagai materi ajar di kelas pada tema cerita rakyat. Folklore Wandiudiu dapat dijadikan materi ajar dalam penelitian tindakan kelas dengan pertimbangan perlunya mengenalkan nilai-nilai kearifan lokal kepada siswa. Hal tersebut sesuai dengan yang tertuang dalam pasal 1 ayat 16 Undang-Undang Republik Indonesia pada Bab 1 Ketentuan Umum.

Hal penting dalam proses pembelajaran yang bisa berdampak pada hasil belajar siswa adalah penggunaan model pembelajaran. Model pembelajaran yang digunakan guru dalam strategi pengajaran juga menunjang keefektifan proses belajar siswa. Pemilihan model pembelajaran yang sesuai dengan materi ajar dan konsdisi siswa di kelas akan menunjang hasil belajar siswa menjadi lebihh baik.

Ada beberapa model pembelajaran yang biasanya digunakan oleh guru dalam membawakan materi ajar cerita rakyat ini, diantaranya model discovery learning dan project based learning (PBL). Akan tetapi, kondisi kelas yang berbeda akan memerlukan model pembelajaran yang berbeda pula sesuai dengan kondisi siswa di dalam kelas. Pada survei yang dilakukan sebelumnya di sekolah, diperoleh informasi dari dua guru mata pelajaran yang mengajar di kelas yang akan menjadi sampel penelitian bahwa sebagian besar siswa di kelas tersebut sulit memahami pelajaran yang diberikan. Pernyataan tersebut tentunya dibuktikan dengan adanya pemerikasaan data yang dilakukan melalui daftar nilai Ulangan Tengah Semester (UTS) yang diperoleh siswa kelas $\mathrm{X}$ IPS 2 SMA Negeri 1 Batauga pada tahun pelajaran 2019/2020. Siswa yang memperoleh nilai sesuai standar nilai kriteria ketuntasan minimal (KKM) ada 16 orang siswa $(57,14 \%)$ dari jumlah keseluruhan siswa sebanyak 28 orang. Sedangkan 12 orang siswa $(42,86 \%)$ belum mencapai standar nilai kriteria ketuntasan minimal (KKM). Data ini diperoleh sebelum diadakan perbaikan nilai oleh guru mata pelajaran.

Kondisi siswa pada kelas demikian membutuhkan peran guru yang lebih dominan. Memperhatikan beberapa permasalahan yang ada khususnya pada kelas X IPS 2 SMA Negeri 1 Batauga, maka perlu diterapkan salah satu model pembelajaran yang sesuai dengan kondisi tersebut. Model pembelajaran yang dipilih tentunya efektif meningkatkan kemampuan siswa memahami nilai yang terkandung dalam folklore Wandiudiu. Oleh karena itu, dipilih model direct instruction karena dalam penerapannya model tersebut berpusat pada arahan guru. Model direct instruction tidak hanya memberikan pengetahuan deklaratif, tetapi juga pengetahuan prosedural, sehingga menunjang siswa memiliki keterampilan dasar yang diajarkan selangkah demi selangkah.

Berdasar pada latar belakang yang diuraikan tersebut, maka rumusan masalah dalam penelitian ini adalah, "Bagaimana penerapan model direct instruction dapat meningkatkan kemampuan siswa SMA Negeri 1 Batauga memahami nilai folkolore Wandiudiu?"

Tujuan dari penelitian ini adalah untuk menjelaskan efektivitas model direct instruction dalam meningkatkan kemampuan siswa SMA Negeri 1 Batauga memahami nilai folklore Wandiudiu.

\section{KAJIAN TEORETIS}


Menurut Amri (2013: 34) model pembelajran memiliki empat ciri sebagai berikut:

a. Rasional teoritik logis, disusun oleh para pencipta dan pengembang model pembelajran.

b. Adanya landasan pemikiran mengenai bagaimana dan untuk apa siswa belajar. Hal ini terkait dengan tujuan pembelajaran yang akan dicapai dalam setiap pokok bahasan.

c. Teknik mengajar yang dilaksanakan sehingga model pembelajaran berhasil diterapkan.

d. Tercapainya tujuan pembeajaran dengan membentuk lingkungan belajar yang kondusif.

Model pembelajaran, dalam penerapannya terdapat langkah-langkah (sintaks) yang dapat menguraikan seluruh langkah yang akan dilaksanakan. Penerapan langkah-langkah tersebut disertai dengan rangkaian kegiatan pembelajaran. Kegiatan yang perlu dilakukan oleh guru dan siswa, tugastugas yang perlu dikerjakan siswa, juga urutan kegiatan dengan jelas diuraikan dalam sintaks pembelajaran. Model pembelajaran yang sesuai dipilih berdasarkan pertimbangan atas keadaan sekolah, kondisi guru, kondisi siswa, fasilitas, media, bahan ajar, dan materi ajar.

Model pembelajaran merujuk pada teknik-teknik yang diterapkan oleh tenaga pengajar, mencakup di dalamnya tentang tahap-tahap yang dilakukan dalam kegiatan pembelajaram, tujuan pembelajaran, lingkungan pembelajaran, dan cara mengelola kelas, Arends (Suprijono, 2013: 46). Pendapat lain juga dikemukakan oleh Joice dan Weil. Menurutnya, model pembelajaran adalah rancangan atau pola yang disusun sedemikan rupa untuk digunakan dalam menyusun kurikulum, menyusun materi ajar, dan memberikan serangkaian petunjuk kepada guru yang mengajar di dalam kelas, Joice dan Weil (Isjoni,
2013: 50). Pendapat lain juga menyatakan bahwa model pembelajaran merupakan serangkaian pemaparan materi pelajaran yang mencakup seluruh aspek dalam proses pembelajaran yang meliputi sebelum, sedang, dan setelah proses pembelajaran tersebut dilakukan oleh guru dan segala fasilitas atau media yang digunakan dalam proses pembelajaran (Istarani, 2014: 1). Proses pembelajaran yang efektif adalah pembelajaran yang melibatkan peserta didik secara aktif. Hal ini dilakukan karena peserta didik merupakan pusat dari serangkaian kegiatan pembelajaran. Selain itu, pembentukan kompetensi dan karakter juga ditujukan kepada peserta didik. Suasana belajar peserta didik dan teknik mengajar seorang guru memengaruhi pemilihan model pembelajaran yang akan digunakan. Metode-metode yang digunakan guru dalam proses pembelajaran di dalam kelas menjadi bagian penting untuk diperhatikan agar rancangan tujuan pembelajaran berhasil dicapai. Itulah sebabnya pemilihan model pembelajaran yang tepat sangat penting dilakukan.

Dari beberapa penjelasan tersebut dapat disimpulkan bahwa model pembelajaran merupakan suatu rangkaian metode atau rencana yang akan diterapkan oleh guru selama berlangsungnya kegiatan pembelajaran di kelas sehingga tujuan pembelajaran dapat tercapai dengan baik..

Direct instruction merupakan model pembelajaran yang sistematis. Gardison dan Vaughan menemukan bahwa direct instruction dapat memberikan proses pembelajaran yang terstruktur, disiplin, sehingga terjadi proses pembelajaran yang bermakna dan berlangsung sistematis. Direct inatruction atau model pembelajaran langsung merupakan salah satu model pembelajaran yang dirancang khusus untuk memberikan pengetahuan 


\section{3 | JURNAL ILMU BUDAY}

Volume 8, Nomor 1, Juni 2020 deklaratif dan pengetahuan prosedural kepada siswa dalam proses pembelajaran. Model direct instruction diterapkan secara terstruktur melalui pola pengajaran bertahap atau diajarkan selangkah demi selangkah. Pengetahuan tentang sesuatu disebut pengetahuan deklaratif, sedangkan bagaimana melakukan sesuatu itu disebut pengetahuan prosedural, Arends (Trianto, 2010: 41).

Pada tahun 1986, Rosenshine dan Steven memperkenalkan model direct instruction atau model pembelajaran langsung untuk pertama kalinya. Direct instruction disebut juga dengan explicit instruction. Ceramah, demonstrasi, praktik atau pelatihan, dan kerja kelompok menjadi ciri dari eksplicit instruction. Model ini mengarahkan guru untuk melakukan strategi demonstrasi, latihan di bawah bimbingan guru atau latihan terpadu, dan penerapan strategi belajar dalam bentuk praktek mandiri.

Model direct instruction merupakan strategi pengajaran yang dirancang sedemikian rupa untuk memudahkan siswa memperoleh pengetahuan deklaratif dan pengetahuan prosedural yang diajarkan secara bertahap atau selangkah demi selangkah dalam proses pembelajaran. Seseorang dapat belajar dengan mudah melalui modeling atau ia langsung mengamati atau meniru perilaku orang lain. Siswa diharapkan mampu menemukan nilai yang terkandung dalam folklore Wandiudiu melalui contoh nyata atau pemodelan yang dilakukan oleh guru. Guru dapat mendemonstrasikan langkahlangkah dalam menceritakan kembali nilai yang terkandung dalam sebuah cerita rakyat sebagai contoh. Model direct instruction memiliki ciri-ciri adanya kegiatan demonstrasi atau pemodelan yang dipraktekkan terkait dengan materi ajar yang bersifat prosedural. Pemodelan ini ditujukan agar siswa mudah memahami tugas-tugas yang diberikan oleh guru. Guru melakukan kegiatan demontrasi atau pemodelan terkait pengetahuan prosedural kepada siswa di awal pembelajaran. Pendemontrasian ini dapat dilakukan dengan menentukan langkahlangkah dalam pembelajara. Langkahlangkah tersebut menuntun siswa untuk memperoleh pengetahuan prosedural. Siswa dibimbing untuk memperoleh keterampilan tertentu sehingga mereka semangat untuk belajar, berpikir, termotivasi untuk ingin tahu, dapat mengambil keputusan yang benar, dan mampu menyelesaikan tugasnya dalam proses pembelajaran.

Watanabe, McLaughlin, Weber, dan Shank (2013) menyatakan bahwa direct instruction adalah salah satu model pembelajaran yang terbagi atas peran guru dalam menjelaskan materi dan memberikan keterampilan baru, mengarahkan guru untuk membagi siswa menjadi beberapa kelompok kecil maupun siswa yang bekerja secara mandiri. Selanjutnya, ada yang berpendapat bahwa fokus model direct instruction adalah pada pencapaian kemampuan siswa sebagai target pembelajaran melalui pemberian tugas berupa pelatihan untuk memperoleh keterampilan, Kinder et.al (Aufan, 2011

Direct instruction merupakan proses pemberian materi ajar dimana yang terlibat dalam menyusun bahan dan materi pelajaran adalah guru yang secara langsung terlibat aktif mengajarkannnya kepada siswa di kelas (Suprijono, 2012: 47). Meskipun direct instruction merupakan model pembelajaran yang berpusat pada guru, namun tetap menjamin terjadinya keterlibatan siswa dalam proses pembelajaran. Santrock (2017: 472) berpendapat bahwa direct intruction merupakan kegiatan pembelajaran yang menjadikan guru sebagai pusat atau pengontrol seluruh proses pembelajaran secara terstruktur. 
Ciri-ciri direct instruction adalah arahan dan kontrol guru sangat dominan, harapan guru yang tinggi utuk tingkat kemampuan siswa dalam belajar, penggunaan waktu secara maksimal untuk menyelesaikan tugas-tugas yang diberikan, dan kiat-kiat yang dilakukan guru untuk mengurangi hal-hal negatif selama proses pembelajaran berlangsung.

\section{a. Tahap-Tahap Model Direct Intruction}

Direct intrsruction terbagi menjadi lima tahap (sintaks) dalam penerapannya. Langkah-langkah tersebut dapat dijelaskan berikut ini.

1) Orientasi (Orientation)

Orientasi merupakan tahap awal dalam penerapan model direct instruction. Pada tahap ini guru menyampaikan kerangka pelajaran terkait dengan materi yang akan diajarkan. Hal-hal yang dapat dilakukan pada tahap ini antara lain: 1) melakukan pendahuluan untuk mengetahui tingkat pengetahuan yang dimiliki siswa terhadap relevansi materi yang akan diajarkan; 2) memberitahukan tujuan pembelajaran; 3) menjelaskan dan mengarahkan kegiatan dan tugas-tugas yang dilakukan siswa; 4) memberitahukan konsep materi yang diajarkan dalam pertemuan di kelas; dan 5) memberitahukan kerangka pelajaran kepada siswa.

\section{2) Presentasi (Presentation)}

Pada tahap ini materi pelajaran seperti konsep-konsep dan keterampilan disampaikan oleh guru. Teknik penyajian meteri dapat dilakukan dengan: 1) menjelaskan materi secara perlahan melalui langkah-langka kecil sehingga siswa dapat memahami materi yang diajarkan dengan baik dalam waktu yang relatif singkat; 2) memberikan contoh konsep; 3) menjelaskan langkahlangkah mengerjakan tugas melalui peragaan keterampilan atau pemodelan dengan melakukan demonstrasi; dan 4) menjelaskan kembali hal-hal yang sulit dipahami siswa.

3) Latihan Terstruktur (Structured
Practice)

Siswa dipandu oleh guru untuk melakukan latihan dalam memperoleh keterampilan terkait dengan materi yang diajarkan. Pada fase ini, hal yang paling penting dilakukan adalah guru memberikan umpan balik terhadap siswa yang merespon materi lalu memberikan dukungan dan penjelasan terhadap respon tersebut. Guru juga perlu memberikan penguatan terhadap jawaban siswa yang benar mengoreksi jawaban siswa yang masih keliru.

\section{4) Latihan Terbimbing (Guided practice)}

Siswa diberi kesempatan untuk melakukan latihan terakit dengan konsep dan keterampilan yang diberikan oleh guru pada tahap ini. Kemampuan siswa dalam mengerjakan tugasnya akan dinilai oleh guru pada saat latihan terbimbing. Guru memberikan bimbingan sembari melakukan pemantauan selama proses latihan ini berlangsung.

5) Latihan Mandiri (Independent
Practice)

Siswa berlatih secara mandiri terkait dengan konsep dan keterampilan yang telah diperoleh. Siswa melakukan kegiatan latihan secara mandiri. Siswa dapat melakukan latihan mandiri apabila telah mahir menguasai $85-90 \%$ pada saat latihan terbimbing, Bruce dan Weil (1996).

\section{b. Sintaks atau Langkah-Langkah Penerapan Model Direct Instruction}

Sofan Amri dan Iif Khoiru (2010: 43-47) membagi sintaks atau langkah-langkah penerapan model direct instruction sebagai berikut:
1) Menyiapkan siswa dan menyampaikan tujuan pembelajaran
a) Menyiapkan siswa 
Guru perlu menyiapkan siswa sebelum pelajaran dimulai. Kegiatan ini dilakukan agar siswa tertarik dengan materi yang akan diajarkan. Pada tahap ini guru memusatkan perhatian siswa pada materi ajar yang akan dibawakan.

b) Menjelaskan tujuan

Guru perlu merumuskan tujuan pembelajaran dan menjelaskannya kepada siswa sebelum pelajaran dimulai. Guru mengomunikasikan tujuan pembelajaran kepada siswa dengan memberitahukan rangkuman kegiatan pembelajaran. Guru dapat menuliskan tujuan pembelajaran ini di papan tulis atau di papan buletin dengan menempelkan informasi tertulis yang berisi langkah-langkah pembelajaran beserta alokasi waktu yang dibutuhkan pada setiap langkah pembelajaran. Siswa dapat melihat seluruh rangkaian tahap pembelajaran yang akan mereka lakukan melalui kegiatan ini.

2) Mendemonstrasikan pengetahun dan keterampilan

a) Memberithukan informasi secara jelas

Guru perlu menyampaikan informasi secara jelas kepada siswa. Informasi disampaikan melalui rancangan pembelajaran dan pengorganisasian kegiatan pembelajaran yang terstrukutr dengan baik. Guru perlu menganalisis keterampilan yang kompleks menjadi lebih sederhana saat melakukan presentasi, kemudian selangkah demi selangkah diajarkan kepada siswa.

b) Melakukan kegiatan demontrasi Siswa memperoleh sebagian besar keterampilan melalui pengamatnnya terhadap orang lain. Model direct instruction digunakan dalam proses pembelajaran agar siswa dapat melihat guru saat memberikan keterampilan. Dalam mendemonstrasikan suatu keterampilan, seorang guru harus mahir memahami konsep dan menguasai keterampilan yang akan diberikan kepada siswa. Guru perlu berlatih melakukan demonstrasi agar dapat menguasai tiap komponen keterampilan yang diajarkan kepada siswa.

3) Mengadakan latihan terbimbing Penerapan direct instruction perlu mengadakan latihan terbimbing. Latihan ini menjadi salah tahap penting selain tahap-tahap lainnya. Siswa yang dilibatkan secara aktif dalam latihan terbimbing akan meningkatkan kemampuannya menguasai konsep dan keterampilan baru. Selain itu, proses belajar dapat berlangung dengan efektif. Pada tahap ini, siswa diajarkan untuk menerapkan konsep dan keterampilan baru.

4) Memberikan umpan balik dan menganalisis pemahaman

Guru perlu menerapkan berbagai teknik dalam merangsang keaktifan siswa di kelas. Guru dapat memberikan umpan balik untuk menganalisis kemampuan siswa. Pada penerapan model direct intruction, tahap ini akan memudahkan guru untuk mengetahui sampai dimana kemampuan siswa dalam memahami konsep dan keterampilan yang diajarkan.

5) Memberikan kesempatan untuk latihan mandiri

Tahap akhir dari penerapan model direct instruction adalah latihan mandiri. Latian mandiri perlu diberikan kepada siswa agar dapat menguasai keterampilan secara mandiri. Guru dapat memberikan pekerjaan rumah kepada siswa terkait konsep dan keterampilan yang telah diajarkan.

\section{METODE PENELITIAN}

Penelitian ini adalah jenis penelitian tindakan kelas yang biasa dikenal dengan isitlah PTK (classroom acyion research). Penelititan tindakan kelas merupakan tindakan atau usaha saat melakukan kegiatan pembelajaran 
agar hasil belajar siswa meningkat. Penelitian dilakukan secara kolaboratif antara guru dan peneliti.

Pelaksanaan penelitian tindakan kelas ini di lakukan di SMA Negeri 1 Batauga kabupaten Buton Selatan. Yang dijadikan sampel pada penelitian ini adalah siswa kelas X IPS 2 sebanyak 28 orang. Jadwal kegiatan penelitian dimulai pada 10 November sampai 13 Desember 2019.

Jenis penelitian ini mengikuti rancangan penelitian tindakan kelas dari Kemmis dan Mc Taggart (Arikunto 2010: 137). Langkah-langkah penelitian tindakan kelas dilakukan lebih dari satu siklus, biasanya dua siklus. Ada empat komponen penting pada setiap siklusnya, yaitu perencanaan, pelaksanaan tindakan, pengamatan, dan refleksi. Keempat langkah tersebut merupakan satu siklus. Setelah langkah keempat dilakukan, guru akan kembali ke langkah pertama, begitu selanjutnya sampai selesai. Secara bersamaan dilakukan pula langkah kedua dan langkah ketiga, meskipun sifatnya berbeda. Pengamatan dapat dilakukan bersamaan ketika pelaksanaan tindakan terjadi.

Pengolahan data dilakukan dengan pendekatan kuantitatif. Pendekatan kuantitatif digunakan untuk memaparkan proses penerapan model direct instruction dan hasil pembelajaran memahami nilai yang terkandung dalam folklore Wandiudiu.

Peningkatan kemampuan siswa ditunjukkan dengan peningkatan nilai yang dipeoleh pada setiap siklus. Parameter untuk mengetahui tingkat keberhasilan siswa menjelaskan nilai yang terkandung dalam cerita rakyat melalui model direct instruction dapat ditetapkan pada tabel 2 berikut ini.

Tabel 1. Parameter Penilaian

\begin{tabular}{|c|c|c|c|}
\hline No. & $\begin{array}{c}\text { Interval Persentase Tingkat } \\
\text { Penguasaan }\end{array}$ & E-A & Keterangan \\
\hline 1. & $90-100$ & A & Sangat Baik \\
\hline 2. & $80-89$ & B & Baik \\
\hline 3. & $70-79$ & C & Sedang \\
\hline 4. & $60-69$ & D & Kurang \\
\hline 5. & $0-50$ & E & Sangat Kurang \\
\hline
\end{tabular}

(modifikasi dari Nurgiyantoro, 2010: 253)

$S=R / N \times 100$

Nilai Hasil Belajar Siswa

Nilai atas hasil belajar dan tugastugas siswa dapat dihitung berdasarkan rumus yang digunakan sebagai berikut:

\section{HASIL DAN PEMBAHASAN}

a. Data dan Analisis Data Pretes Kelas $\mathrm{X}$ IPS 2

Sebelum menerapkan model
direct instruction, terlebih dahulu
diadakan pretes di kelas X IPS 2.
Kegiatan ini dilakukan untuk
mengetahui kemampuan siswa dalam
pembelajara menjelaskan nilai yang
terkandung dalam cerita rakyat. Adapun
Keterangan:

$\mathrm{S}=$ nilai

$\mathrm{R}=$ Jumlah skor dari soal yang dijawab dengan benar

$\mathrm{N}=$ skor maksimum dari hasil tes

pemerolehan nilai pretes pada kelas $X$ IPS 2 dapat digambarkan pada tebel berikut ini.

Nilai Religius

Pada aspek nilai religius, sebanyak empat orang siswa mendapat nilai 75 ; terdapat sepuluh orang siswa mendapat nilai 70 ; terdapat delapan orang siswa mendapatkan mendapat nilai 65; dan terdapat enam orang siswa mendapat nilai 60. Pemerolehan nilai 
rata-rata pada aspek nilai religius mencapai nilai sebesar 67,14. Untuk mengetahui klasifikasi nilai kelas X IPS
2 pada aspek nilai religius, dapat diamati melalui tabel berikut ini.

Tabel 2. Klasifikasi Aspek Nilai Religius Kelas X IPS 2

\begin{tabular}{|c|c|c|c|c|}
\hline NO. & $\begin{array}{l}\text { Interval Persentase } \\
\text { Tingkat Penguasaan }\end{array}$ & Frekuensi & $\begin{array}{c}\text { Presentase } \\
\%\end{array}$ & Keterangan \\
\hline 1. & $90-100$ & - & - & sangat tinggi \\
\hline 2. & $80-89$ & - & - & tinggi \\
\hline 3. & $70-79$ & 14 & 50 & sedang \\
\hline 4. & $60-69$ & 14 & 50 & rendah \\
\hline \multicolumn{2}{|r|}{ Jumlah } & 28 & $100 \%$ & \\
\hline
\end{tabular}

Pada tabel di atas menunjukkan bahwa tidak ada siswa yang memperoleh kategori nilai tinggi dan sangat tinggi. Kemudian yang memperoleh kategori sedang sebanyak 14 orang siswa atau $(50 \%)$. Selanjutnya, siswa yang memperoleh nilai dengan kategori rendah terdapat 14 orang siswa $(50 \%)$. Hasil ini menunjukkan bahwa tingkat kompetensi menjelaskan nilai yang terkandung dalam folklore Wandiudiu pada aspek nilai relilgius dikategorikan sedang.

\section{Nilai Moral}

Pada aspek nilai moral, sebanyak tiga orang siswa mendapat nilai 75 ; kemudian ada sebelas orang siswa mendapat nilai 70 ; ada sepuluh orang siswa mendapat nilain 65 ; dan sebayak empat siswa mendapat nilai 60 . Pemerolehan nilai rata-rata pada aspek nilai moral mencapai nilai sebesar 67,32. Untuk mengetahui klasifikasi nilai pada kelas X IPS 2, dapat diamati pada tabel berikut ini.

Tabel 3. Klasifikasi Aspek Nilai Moral Kelas X IPS 2

\begin{tabular}{|c|c|c|c|c|}
\hline NO. & $\begin{array}{c}\text { Interval Persentase } \\
\text { Tingkat Penguasaan }\end{array}$ & Frekuensi & $\begin{array}{c}\text { Persentase } \\
\mathbf{\%}\end{array}$ & Keterangan \\
\hline 1. & $90-100$ & - & - & sangat tinggi \\
\hline 2. & $80-89$ & - & - & tinggi \\
\hline 3. & $70-79$ & 14 & 50 & sedang \\
\hline 4. & $60-69$ & 14 & 50 & rendah \\
\hline \multicolumn{2}{r}{} & $\mathbf{2 8}$ & $\mathbf{1 0 0 \%}$ & \\
\hline
\end{tabular}

Pada tabel di atas menunjukkan bahwa tidak ada satu pun siswa yang mendapat nilai dengan kategori tinggi dan sangat tinggi. Siswa yang memperoleh nilai dengan kategori sedang sebanyak 14 orang atau (50\%). Kemudian siswa yang memperoleh kategori nilai rendah berjumlah 14 orang siswa $(50 \%)$. Hasil ini menunjukkan bahwa tingkat kompetensi menjelaskan nilai yang terkandung dalam folklore
Wandiudiu pada aspek nilai moral dikategorikan rendah.

Nilai Sosial

Pada aspek nilai sosial, sebanyak lima orang siswa mendapat nilai 75 ; kemudian yang mendapat nilai 70 ada delapan orang siswa; yang mendapat nilai 65 ada sebelas orang siswa; dan ada empat orang siswa mendapat nilai 60. Pemerolehan nilai rata-rata pada aspek nilai sosial mencapai nilai sebesar 67,5. Untuk 
mengetahui klasifikasi nilai kelas X IPS

pada tabel berikut ini.

2 pada aspek nilai sosial, akan diruraikan

Tabel 4. Klasifikasi Aspek Nilai Sosial Kelas X IPS 2

\begin{tabular}{|c|c|c|c|c|}
\hline No. & $\begin{array}{l}\text { Interval Persentase } \\
\text { Tingkat Penguasaan }\end{array}$ & Frekuensi & $\begin{array}{c}\text { Persentase } \\
\%\end{array}$ & Keterangan \\
\hline 1. & $90-100$ & - & - & sangat tinggi \\
\hline 2. & $80-89$ & - & - & tinggi \\
\hline 3. & $70-79$ & 13 & 46 & sedang \\
\hline 4. & $60-69$ & 15 & 54 & rendah \\
\hline & Jumlah & 28 & $100 \%$ & \\
\hline
\end{tabular}

Pada tabel di atas menunjukkan bahwa tidak satu pun siswa mendapatkan nilai dengan kategori sangat tinggi. Selanjutnya, yang mendapatkan kategori nilai sedang ada 13 orang siswa (46\%). Kategori nilai rendah diperoleh sebanyak 15 orang siswa $(54 \%)$. Hasil ini menunjukkan bahwa tingkat kompetensi menjelaskan nilai yang terkandung dalam folklore Wandiudiu pada aspek nilai sosial dikategorikan sedang.

\section{Nilai Budaya}

Pada aspek nilai budaya, sebanyak satu orang siswa mendapat nilai 80 ; ada lima orang siswa mendapat nilai 75 ; ada sepuluh orang siswa mendapat nilai 70; ada enam orang siswa mendapat nilai 65; dan sebayak enam siswa memperoleh nilai 60 . Pemerolehan nilai pada aspek nilai budaya mencapai nilai sebesar 68,03. Untuk mengetahui klasifikasi nilai pada kelas X IPS 1, akan diuraikan pada tabel berikut ini.

Tabel 5. Klasifikasi Aspek Nilai Budaya Kelas X IPS 2

\begin{tabular}{|c|c|c|c|c|}
\hline No. & $\begin{array}{l}\text { Interval Persentase } \\
\text { Tingkat Penguasaan }\end{array}$ & Frekuensi & $\begin{array}{c}\text { Persentase } \\
\%\end{array}$ & Keterangan \\
\hline 1. & $90-100$ & - & - & sangat tinggi \\
\hline 2. & $80-89$ & 1 & 3 & tinggi \\
\hline 3. & $70-79$ & 15 & 54 & sedang \\
\hline 4. & $60-69$ & 12 & 43 & rendah \\
\hline \multicolumn{2}{|r|}{ Jumlah } & 28 & $100 \%$ & \\
\hline
\end{tabular}

Pada tabel di atas disimpulkan bahwa tidak satu pun siswa yang mendapat niali dengan kategori sangat tinggi. Kemudian siswa yang mendapat nilai dengan kategori tinggi sebanyak 1 orang (3\%). Selanjutnya, ada 15 orang siswa $(54 \%)$ yang mendapat nilai dengan kategori sedang. Siswa yang memperoleh nilai dengan kategori rendah sebanyak 12 orang $(43 \%)$. Hasil ini menunjukkan bahwa tingkat kompetensi siswa menjelaskan nilai yang terkandung dalam folklore Wandiudiu pada aspek nilai budaya dikategorikan sedang.
Setelah melihat pemerolehan nilai cerita rakyat pada pretes kelas $\mathrm{X}$ IPS 2, dapat disimpulkan bahwa pencapaian nilai ketuntasan maksimal siswa pada pembelajaran cerita rakyat termasuk dalam kategori kurang. Hal ini dapat dilihat pada pemerolehan nilai rata-rata siswa yang berada pada angka 67,49 . Kategori ini didasarkan pada parameter penelitian yang ada di tabel 2 . Adapun perolehan nilai secara keseluruhan dapat dilihat pada tabel berikut. 
Tabel 6. Perolehan Nilai Folklore Wandiudiu Kelas X IPS 2 pada Tahap Pretes

\begin{tabular}{|c|c|c|}
\hline No & Aspek yang Dinilai & Pemerolehan \\
\hline 1 & Nilai religius & 67,14 \\
\hline 2 & Nilai moral & 67,32 \\
\hline 3 & Nilai sosial & 67,5 \\
\hline 4 & Nilai budaya & 68,03 \\
\hline \multicolumn{2}{|c|}{ Jumlah } & 269,99 \\
\hline & Rata-rata & 67,49 \\
\hline
\end{tabular}

Hasil pretes menunjukkan pemerolehan nilai rata-rata siswa berada pada kategori nilai kurang. Setelah melakukan pretes, peneliti memberikan arahan kepada guru mata pelajaran bahasa Indonesia untuk menggunakan model direct instruction dalam proses pembelajaran. Model ini diterapkan dengan tujuan dapat meningkatkan nilai belajar siswa, khususnya pada materi folklore. b. Penyajian Data Hasil Pembelajaran Memahami Nilai dalam Folklore Wandiudiu Siswa Kelas X IPS 1 SMA Negeri 1 Batauga

a) Siklus 1

Melalui model direct instruction, berikut dipaparkan hasil belajar memahami nilai yang terkandung dalam folklore Wandiudiu kelas X IPS 2.

Tabel 3. Perolehan Nilai Folklore Wandiudiu Kelas X IPS 2 Siklus I

\begin{tabular}{|c|c|c|}
\hline No & Aspek yang Dinilai & Pemerolehan \\
\hline 1 & Nilai religius & 77,67 \\
\hline 2 & Nilai moral & 78,39 \\
\hline 3 & Nilai sosial & 79,28 \\
\hline 4 & Nilai budaya & 80,17 \\
\hline \multicolumn{2}{|c|}{ Jumlah } & 315,51 \\
\hline \multicolumn{2}{|c|}{ Rata-rata } & 78,87 \\
\hline
\end{tabular}

Setelah melihat pemerolehan nilai kemampuan siswa memahami nilai yang terkandung dalam folklore Wandiudiu pada siklus I tersebut, maka dapat disimpulkan pencapaian nilai ketuntasan maksimal siswa pada pembelajaran memahami nilai dalam folklore Wandiudiu berada pada kategori sedang dengan nilai rata-rata 78,87 . Kategori ini dapat dilihat pada parameter penelitian yang ada di tabel 1 .

b) Siklus II

Pemerolehan nilai siswa memahami nilai yang terkandung dalam folklore Wandiudiu pada siklus II dapat digambarkan berikut ini.

Tabel 4. Perolehan Nilai Folklore Wandiudiu Kelas X IPS 2 Siklus II

\begin{tabular}{|c|c|c|}
\hline No & Aspek yang Dinilai & Pemerolehan \\
\hline 1 & Nilai religius & 83,75 \\
\hline 2 & Nilai moral & 85,17 \\
\hline 3 & Nilai sosial & 84,82 \\
\hline
\end{tabular}




\begin{tabular}{|c|c|c|}
\hline 4 & Nilai budaya & 86,96 \\
\hline \multicolumn{2}{|c|}{ Jumlah } & 340,7 \\
\hline \multicolumn{2}{|c|}{ Rata-rata } & 85,17 \\
\hline
\end{tabular}

Setelah melihat pemerolehan nilai kemampuan siswa memahami nilai yang terkandung dalam folklore Wandiudiu pada siklus II, maka dapat disimpulkan pencapaian nilai ketuntasan maksimal siswa pada pembelajaran memahami nilai dalam folklore Wandiudiu dikategorikan baik dengan peolehan nilai rata-rata 85,17 berada pada kategori baik dengan nilai rata-rata 85,17 . Kategori tersebut dapat dilihat pada parameter penelitian yang ada di tabel 2.

Tebel di atas menunjukkan terjadi peningkatan hasil pembelajaran siswa. Dilihat pada perolehan rata-rata nilai yang didapatkan siswa pada siklus I sebesar 78,87, kemudian pada siklus II perolehan rata-rata nilai sebesar 85,17. Setelah melihat pemerolehan nilai tersebut, dapat disimpulkan bahwa model direct instruction efektif meningkatkan hasil belajar siswa SMA Negeri 1 Batauga untuk memahami nilai yang terkandung dalam folklore Wandiudiu.

\section{KESIMPULAN}

Berdasarkan penerapan model pembelajaran, hasil, dan pembahasan dalam penelitian ini, maka beberapa hal dapat disimpulkan bahwa proses pembelajaran memahami nilai dalam folklore Wandiudiu dengan menerapkan model direct instruction pada siswa kelas X IPS 2 SMA Negeri 1 Batauga mengalami peningkatan. Peningkatan hasil pembelajaran dapat dilihat pada aktivitas siswa dan guru selama siklus pembelajaran berlangsung. Pada siklus I, terlihat pada beberapa tahap siswa kurang aktif. Selain itu, ada pula aktivitas guru yang tidak terlaksana.
Pada siklus II, aktifitas guru dan siswa berlangsung maksimal. Pada siklus II, guru dan siswa aktif dalam proses pembelajaran.

Kemampuan siswa SMA Negeri 1 Batauga memahami nilai yang terkadung dalam folklore Wandiudiu setelah menerapkan model direct instruction mengalami peningkatan. Hal tersebut dapat dilihat dari nilai belajar siswa pada kelas X IPS 2. Pada kelas tersebut, hasil belajar siswa memperlihatkan perbedaan yang cukup signifikan. Siklus I mencapai nilai ratarata 78,87 yang berarti berada pada kategori sedang, dan siklus II mencapai nilai rata-rata 85,17 yang berarti berada pada katgori baik. Hal ini menunjukkan bahwa hasil belajar siswa dalam memahami nilai yang terkandung dalam folklore Wandiudiu mengalami peningkatan setelah menerapkan model direct instruction.

Penulis dapat menyampaikan beberapa saran berdasarkan pada kesimpulan hasil penelititan di atas. Model direct insruction dapat direkomendasikan kepada guru untuk digunakan di dalam kelas sebagai salah satu model pembelajaran yang dapat meningkatkan hasil belajar siswa. Bagi siswa, hendaknya selalu memotivasi diri dalam belajar, terutama juga mempelajari nilai-nilai kearifan lokal pada materi yang relevan dengan muatan kurikulum bahasa Indonesia. Kepada peneliti selanjutnya, agar dapat melakukan penelitian terkait model pembelajaran yang berbeda sehingga ditemukan berbagai model yang dapat digunakan dalam pembelajaran memahami nilai yang terkandung dalam sebuah folklore. 


\section{1 | JURNAL ILMU BUDAYA}

Volume 8, Nomor 1, Juni 2020

\section{DAFTAR PUSTAKA}

Amintoko, Gunanto. 2017. Model Pembelajaran Direct Instruction dalam Meningkatkan Pemahaman Konsep dan Hasil Belajar Definisi Limit bagi Mahasiswa. Journal Unsika, 1 (1), $1-12$.

Amri, Sofan. 2013. Pengembangan dan Model Pembelajaran dalam Kurikulum 2013. Jakarta: Prestasi Pustakarya.

Arafah, Burhanuddin, Hasyim, Muhammad. 2019. Linguistic functions of emoji in social media communication. Opcion. 25 (24), 558-574.

Arafah, Burhanuddin and Hasyim, Muhammad. 2019. The Language of Emoji in Social Media. in The Second Annual International Conference on Language and Literature, $\mathrm{KnE}$ Social Sciences, pages 494-504.

Bahar, Andi Kaharuddin, Latif, Ismail. 2019. Society-Based English Community (SOBAT): EFL Learners' Strategy in Learning and Practicing English Outside The Walls. Jurnal Ilmu Budaya. 7 (2), 255-265.

Budiningsih, Aris. 2012. Belajar dan Pembelajaran. Jakarta: Rineka Cipta.

Danandjaja, James. 2007. Folklor Indonesia, Ilmu Gosip, Dongeg, dan lain-lain. Jakarta: Grafiti.
Djamarah, Bahri, Syaiful. 1981. Prestasi Belajar dan Kompetensi Guru. Surabaya: Usaha Nasioal. Joyce, Bruce,dkk. 2009. Models Of Teaching. Yogjakarta: Pustaka pelajar. Kemmis, S. \& Mc Taggart, R. 1988. The Action Research Planner. Australia: Deakin University Press.

Neisser, Uris. 1976. Cognition and Reality: Principles and Implication of Cognitive Psycology. San Fransisco: Freman and Company.

Nur, M dan Kardi, S. 2000 Pengajaran Langsung. Pusat Sains dan Matematika. Sekolah Program Pasca Sarjana. UNESA.

Santrock, John W. 2017. Educational Psychology. New York: McGraw-Hill Companies.

Sudjana, Nana. 2004. Dasar-Dasar Proses Belajar Mengajar. Bandung: Sinar Baru Algesindo.

Sugihartono, dkk. 2007. Psikologi Pendidikan. Yogyakarta: UNY Press

Suprijono, Agus. 2012. Cooperative Learning. Jogjakarta: Pustaka Belajar.

Suyitno. 1986. Sastra, Tata Nilai, dan Eksegesis. Yogyakarta: Hanindita.

Trianto. 2010. Mendesain Model Pembelajaran Inovatif-Progresif. Jakarta: Kencana Prenada Media group.

Wellek, Rene \& Austin Warren. 2014. Teori Kesusasteraan (terjemahan). Jakarta: Gramedia Pustaka Utama. 